Provided for non-commercial research and education use. Not for reproduction, distribution or commercial use.

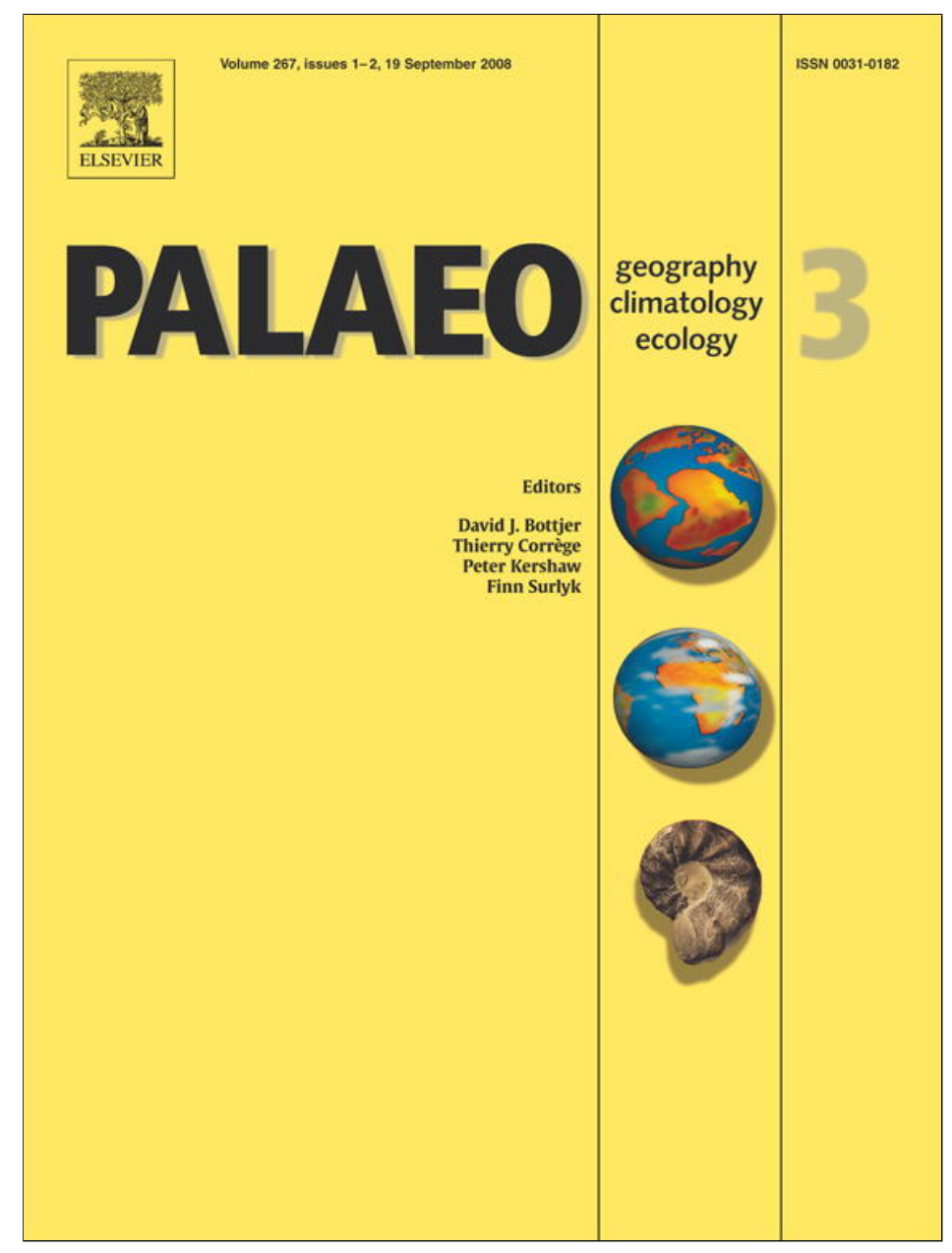

This article appeared in a journal published by Elsevier. The attached copy is furnished to the author for internal non-commercial research and education use, including for instruction at the authors institution and sharing with colleagues.

Other uses, including reproduction and distribution, or selling or licensing copies, or posting to personal, institutional or third party websites are prohibited.

In most cases authors are permitted to post their version of the article (e.g. in Word or Tex form) to their personal website or institutional repository. Authors requiring further information regarding Elsevier's archiving and manuscript policies are encouraged to visit:

http://www.elsevier.com/copyright 


\title{
Early Holocene environments on October Revolution Island, Severnaya Zemlya, Arctic Russia
}

\author{
A.A. Andreev ${ }^{\text {a, } *}$, D.J. Lubinski ${ }^{b}$, A.A. Bobrov ${ }^{c}$, Ó. Ingólfsson ${ }^{d}$, S.L. Forman ${ }^{e}$, P.E. Tarasov ${ }^{f}$, P. Möller ${ }^{g}$ \\ a Alfred-Wegener-Institut für Polar- und Meeresforschung, Forschungsstelle Potsdam, Telegrafenberg A43, 14473 Potsdam, Germany \\ ${ }^{\mathrm{b}}$ Institute of Arctic and Alpine Research (INSTAAR), Campus Box 450, University of Colorado, Boulder, CO 80309-0450, USA \\ c Soil Department of Moscow State University, Vorobievy Gory, 119899, Moscow, Russia \\ d Department of Geology and Geography, Askja, University of Island, IS-101 Reykjavík, Iceland \\ e Department of Earth and Environmental Sciences, University of Illinois at Chicago, 845 W. Taylor Street, Chicago, IL 60607-7059, USA \\ ${ }^{\mathrm{f}}$ Institute for Geological Sciences/Palaeontology Free University Berlin, Malteserstrasse 74-100, 12249 Berlin, Germany \\ g GeoBiosphere Science Centre, Department of Geology, Quaternary Sciences, Lund University, Sölvegatan 12, SE-22362 Lund, Sweden
}

\section{A R T I C L E I N F O}

\section{Article history:}

Received 14 January 2008

Received in revised form 7 April 2008

Accepted 16 May 2008

\section{Keywords:}

Early Holocene

Pollen and palynomorphs

Rhizopods

Russian High Arctic

\begin{abstract}
A B S T R A C T
Pollen, palynomorphs, and rhizopods were studied from several $<1 \mathrm{~m}$ thick, peaty and silty sediment sections on southwestern October Revolution Island, Severnaya Zemlya. Six AMS radiocarbon ages from the sections show that peat accumulation started at ca. 11,500 and stopped after $9500 \mathrm{cal}$. yr BP, consistent with several previously reported ${ }^{14} \mathrm{C}$ ages. Open steppe-like vegetation existed on the island during the late Glacial, shortly before the Pleistocene/Holocene transition. Environmental conditions on the island were most favourable for local biota during the early Holocene, ca. 11,500-9500 cal. yr BP, when tundra-like sedgegrass communities dominated the vegetation. Low shrub tundra associations with dwarf birch and willow grew in more wind-sheltered localities. The temperatures during the growing season were at least $4{ }^{\circ} \mathrm{C}$ higher than today. The Vavilov Ice Cap was at or behind its present margins. Environmental conditions in the region changed significantly ca. 9400 cal. yr BP as a result of colder and drier conditions, when vegetation became similar to the modern, sparse lichen-moss-grass cover.
\end{abstract}

(C) 2008 Elsevier B.V. All rights reserved.

\section{Introduction}

Although recent palaeoenvironmental studies on the Severnaya Zemlya archipelago have revealed a long and complex history of glaciations and associated sea-level changes from the middle to the late Pleistocene (Bolshiyanov and Makeyev, 1995; Andreev et., al., 1997a; Raab et al., 2003; Möller et al., 2007), relatively little is known about environmental changes during and after the Pleistocene/ Holocene transition (ca. 11,500 cal. yr to present). The early Holocene is an especially intriguing period based on a brief mention by Arslanov et al. (1980) of a peat deposit containing moss, herbs, and twigs which were radiocarbon dated to $11,477 \pm 177 \mathrm{cal}$. yr BP, indicating the dominance of shrub tundra. Later, this single datum point was supplemented (Makeyev et al., 1992; Bolshiyanov and Makeyev, 1995) with the identification of twig remains of dwarf willow and birch, including dwarf willow found near Changeable Lake dated to 11,692 \pm 243 cal. yr BP (Bolshiyanov and Makeyev, 1995). Pollen of these taxa and Poaceae and Cyperaceae were identified in sediments radiocarbon dated to $10,961 \pm 169$ and $13,440 \pm 455$ cal. yr BP. However, pollen count data were not reported, so the full pollen spectra remain

\footnotetext{
* Corresponding author.

E-mail address: aandreev@awi-potsdam.de (A.A. Andreev).
}

unknown. Most of the samples dated thus far were collected within a few $\mathrm{km}$ of the present ice-cap margins, some immediately adjacent to the ice. These samples show that the ice caps extent were similar to or smaller than present in the early Holocene (Stiévenard et al., 1996). A number of ice cores drilled on the Archipelago, some up to $725 \mathrm{~m}$ long, have the potential to help reconstruct past ice-cap dimension and environmental conditions for the early Holocene to the present. However, these chronologies remain hotly debated, with two estimates for the basal age of the oldest core (Akademii Nauk) diverging enormously: ca. 14,000 and 2500 cal. yr. The latter age is based on the most recently collected core (Fritzsche et al., 2005), and implies that glaciers may have been absent for much of the early and middle Holocene.

These sparse observations present intriguing preliminary evidence suggesting ameliorated environmental conditions during the early Holocene (especially ca. 11,500 cal. yr), similar to other regions of the high Arctic (i.e., Andreev et al., 1997b; Serebryanny et al., 1998; Andreev et al., 2003, 2005). Additional studies on Severnaya Zemlya are needed to reconstruct better past vegetation assemblages and determine the timing and magnitude of environmental changes (i.e. growing season temperature). We present new palaeoenvironmental data based on five disjunct $<1 \mathrm{~m}$ thick peaty and silty sections, all but one of which were described and sampled on southwestern 
October Revolution Island, close to the present Vavilov Ice-Cap margin, during a joint Swedish-American-Russian expedition in 2002 (see Möller et al., 2007). The fifth section, located on Bolshevik Island, was previously studied by Raab (2003) and we have added new data to this record. Our study focuses on palynological and rhizopod (protozoan) records of the early Holocene and associated inferred palaeoenvironmental changes.

\section{Study area}

October Revolution Island is situated on the Siberian continental shelf (Fig. 1) and is the largest island of the Severnaya Zemlya archipelago. Cambrian and Devonian bedrock outcrops over large areas, but elsewhere it is covered by a relatively thin blanket of Quaternary deposits and periglacial regolith (Bolshiyanov and

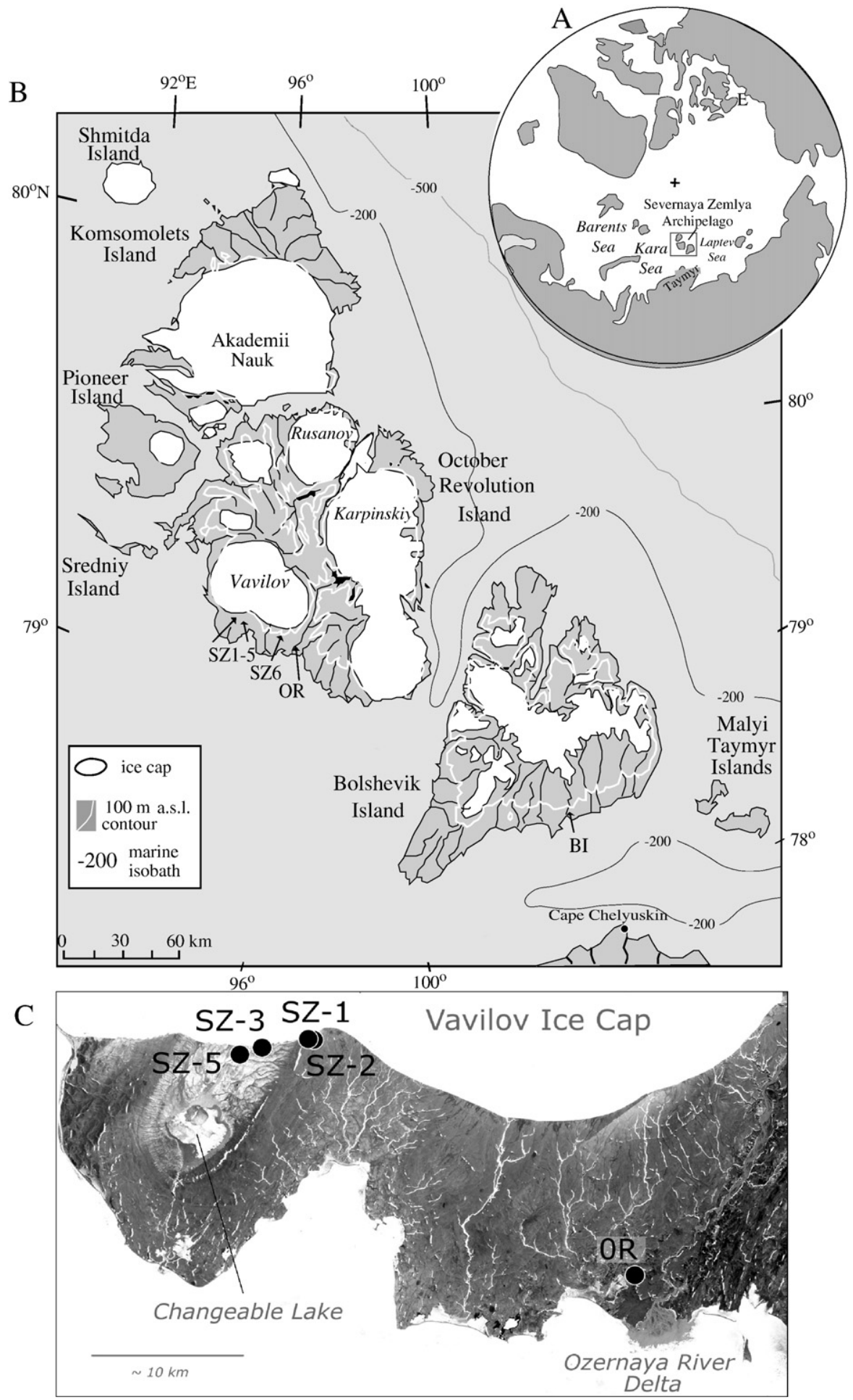

Fig. 1. A. Map of the Arctic. B. Map of the Severnaya Zemlya Archipelago. C. Study area on the October Revolution Island. Locations of the studied profiles and surface samples are in Table 1. 
Table 1

Locations of the peaty profiles and surface samples

\begin{tabular}{|c|c|c|c|c|c|}
\hline Region & Site ID & Field ID & $\begin{array}{l}\text { Latitude } \\
\text { (N) }\end{array}$ & $\begin{array}{l}\text { Longitude } \\
\text { (E) }\end{array}$ & $\begin{array}{l}\text { Thickness } \\
(\mathrm{cm})\end{array}$ \\
\hline \multicolumn{6}{|c|}{ Southwestern October Revolution Island } \\
\hline Changeable Lake & SZ-2 & TH-2 & $79^{\circ} 10.571^{\prime}$ & $95^{\circ} 29.716^{\prime}$ & 30 \\
\hline Changeable Lake & SZ-5 & 5 & $79^{\circ} 10.163^{\prime}$ & $95^{\circ} 16.291^{\prime}$ & 20 \\
\hline Changeable Lake & SZ-3 & 3 & $79^{\circ} 10.298^{\prime}$ & $95^{\circ} 20.724^{\prime}$ & 95 \\
\hline Changeable Lake & SZ-1a-b-c & TH-1 & $79^{\circ} 10.558^{\prime}$ & $95^{\circ} 30.125^{\prime}$ & $30,30,10$ \\
\hline Ozernaya River delta & OR & Lagoon & $79^{\circ} 01.051^{\prime}$ & $96^{\circ} 29.664^{\prime}$ & 60 \\
\hline Changeable Lake & SZ-20 & SZ 1 & $79^{\circ} 09.36^{\prime}$ & $95^{\circ} 53^{\prime}$ & Surface sample \\
\hline Changeable Lake & SZ-21 & SZ 2 & $79^{\circ} 08.72^{\prime}$ & $95^{\circ} 20.724^{\prime}$ & Surface sample \\
\hline Ozernaya River & SZ-24 & SZ 5 & $79^{\circ} 09.34^{\prime}$ & $96^{\circ} 53.968^{\prime}$ & Surface sample \\
\hline \multicolumn{6}{|l|}{ Bolshevik Island } \\
\hline Solnechnaya Bay & BI & & $78^{\circ} 14^{\circ}$ & $103^{\circ} 10^{\prime}$ & 13 \\
\hline
\end{tabular}

Makeyev, 1995). The geomorphology of the non-glaciated areas is characterized by broad valleys and extensive flat lowlands below $100 \mathrm{~m}$ a.s.l., dissected by a number of river valleys and ravines of which the largest are those of the rivers draining the Vavilov and Karpinskiy Ice Caps (Möller et al., 2007). The studied peat and silt profiles were collected from banks of small streams eroded into the flat lowlands along the Vavilov Ice Cap and in the Ozernaya River valley.

The present climate is extremely harsh with a mean annual air temperature of about $-13^{\circ} \mathrm{C}$ (Bolshiyanov and Makeyev, 1995). Mean monthly temperatures for July and August are near $0{ }^{\circ} \mathrm{C}$, but there is substantial daily variability. Daily temperatures well above freezing occur with warm air masses sourced from northern Siberia (Bassford et al., 2006). Colder temperatures are common with the persistence of cloudy, foggy and windy conditions and summer snowfall is not unusual. Colder conditions prevail with katabatic winds occasionally blow from the ice caps. In some years, particularly in September there are one or more marked warming events lasting several days with associated surface melting of the ice caps (Bassford et al., 2006). The annual precipitation ranges from 240 to $400 \mathrm{~mm}$, with most of the precipitation falling as snow.

The archipelago is in the polar desert zone with patchy, poorly developed polar desert, arctic, and peaty soils (Govorenkov, 1981). Generally, vegetation cover is very scarce $(<10 \%)$ with the predomi- nance of lichens-moss-grass communities. On south-and-west-facing slopes shielded from prevailing winds (e.g. Ozernaya River basin), plant communities are richer, with the occurrence of dwarf willows, Salix polaris, and S. reptans (Korotkevich, 1958). Only 71 species of vascular plants have been described from October Revolution Island (Safronova, 1981; Khodachek, 1986).

\section{Methods}

Six short sediment profiles were described from the Changeable Lake and the Ozernaya River basins (Fig. 1) on October Revolution Island and sampled for ${ }^{14} \mathrm{C}$ dating and palynological and rhizopod analyses. Samples were taken from vertical sections in frozen deposits. Samples from an additional profile on Bolshevik Island (Raab, 2003) were analyzed for rhizopods. The locations of the studied profiles are listed in Table 1.

Samples for ${ }^{14} \mathrm{C}$ dating were wet-sieved, macrofossils were hand picked from the samples, rinsed in deionized water, and dried. The samples received a standard acid-base-acid pretreatment after submission to the NSF Arizona AMS Facility. The results are presented in Table 2. The Calpal program (http://www.calpal-online.de/) was used to calibrate the ${ }^{14} \mathrm{C}$ ages.

A standard HF technique was used for pollen preparation (Berglund and Ralska-Jasiewiczowa, 1986). The samples were investigated under a light microscope at 200-400× magnifications. At least 200 pollen grains were counted for each organic-rich sample. Generally, the number of counted pollen grains was less in pollenpoor silt samples. Pollen concentration was calculated in grains per gram. The relative frequencies of pollen taxa were calculated using sum of the terrestrial pollen taxa. Spore percentages are based on the sum of pollen and spores. The relative abundances of reworked taxa (Tertiary spores and redeposited Quaternary pollen) were based on the sum of pollen and redeposited taxa, and the percentages of algae were based on the sum of pollen and algae. Tilia/TiliaGraph software (Grimm, 1991) was used for the calculation of percentages and for drawing the diagrams. Diagrams were zoned by visual inspection.

The quantitative method known as the best modern analogue (BMA) approach (e.g. Guiot, 1990) was used to reconstruct past climate variables from the early Holocene pollen spectra. The same approach has already been used to infer palaeoclimatic signals from

Table 2

Late Glacial and Holocene radiocarbon dates from October Revolution (SZ), Bolshevik (BI), and Komsomolets (KI) Islands

\begin{tabular}{|c|c|c|c|c|c|c|}
\hline $\begin{array}{l}\text { Sample ID } \\
\text { (depth, cm) }\end{array}$ & Fraction dated & $\begin{array}{l}\text { Radiocarbon age } \\
\left({ }^{14} \mathrm{C} \text { yr BP }\right)\end{array}$ & $\begin{array}{l}\text { Calibrated age } \\
\text { (cal yr BP) }\end{array}$ & $\begin{array}{l}\delta^{13} \mathrm{C} \\
(\%)\end{array}$ & Lab. no & Reference \\
\hline SZ, site 103 & Plant remains* & $11,460 \pm 410$ & $13,440 \pm 455$ & & LU-1127 & Bolshiyanov and Makeyev, 1995 \\
\hline SW Universitetskiy Ice Cape & Mammoth tusk & $11,500 \pm 60$ & $13,403 \pm 121$ & & LU-610 & Makeyev et al., 1979; Arslanov et al., 1980 \\
\hline E Vavilov Ice Cape & Mammoth tusk & $10,450 \pm 110$ & $12,254 \pm 214$ & & LuA-4820 & Möller et al., 2007 \\
\hline SZ, site 31 & Dwarf willow & $10,100 \pm 100$ & $11,692 \pm 243$ & & LU-1161 & Bolshiyanov and Makeyev, 1995 \\
\hline SZ, site $80,30-45$ & Peat* & $9950 \pm 100$ & $11,477 \pm 177$ & & LU-655 & Arslanov et al., 1980 \\
\hline SZ-2, 15-20 & Plant remains* & $9810 \pm 45$ & $11,229 \pm 20$ & -27.5 & CURL-6932 & This study \\
\hline SZ, site 103 & Plant remains* & $9620 \pm 110$ & $10,961 \pm 169$ & & LU-1120 & Bolshiyanov and Makeyev, 1995 \\
\hline SZ-5, 40-45 & Plant remains* & $9440 \pm 45$ & $10,670 \pm 57$ & -28.3 & CURL-6931 & This study \\
\hline SZ-5, 30-35 & Plant remains* & $9250 \pm 55$ & $10,415 \pm 91$ & -26.3 & CURL-6930 & This study \\
\hline$S Z-3,75-80$ & Plant remains* & $9020 \pm 50$ & $10,199 \pm 31$ & -27.7 & CURL-6935 & This study \\
\hline SZ-1A, 25-30 & Plant remains* & $8770 \pm 40$ & $9811 \pm 145$ & -26.0 & CURL-6933 & This study \\
\hline SZ, site 103 site 93 & Plant remains* & $8800 \pm 200$ & $9884 \pm 250$ & & & Bolshiyanov and Makeyev, 1995 \\
\hline SZ-1B, $45-50$ & Plant remains* & $8580 \pm 60$ & $9569 \pm 50$ & -29.1 & CURL-6934 & This study \\
\hline SZ, an alluvial terrace, 303 & Plant detritus & $3400 \pm 90$ & $3664 \pm 124$ & & LU-1123 & Bolshiyanov and Makeyev, 1995 \\
\hline SZ, an alluvial terrace, 420 & Plant detritus & $3280 \pm 130$ & $3534 \pm 145$ & & LU-1125 & Bolshiyanov and Makeyev, 1995 \\
\hline SZ, site 103 site 93 & Plant remains? & $3200 \pm 100$ & $3434 \pm 116$ & & & Bolshiyanov and Makeyev, 1995 \\
\hline SZ, site 103 site 93 & Plant remains? & $910 \pm 1000$ & $1270 \pm 869$ & & & Bolshiyanov and Makeyev, 1995 \\
\hline $\mathrm{BI}, 0-10$ & Willow remains & $8790 \pm 60$ & $9859 \pm 149$ & -30.0 & UtC-7429 & Raab, 2003 \\
\hline BI, 0-10 & Insect remains & $8650 \pm 60$ & $9628 \pm 63$ & -35.9 & UtC-7430 & Raab, 2003 \\
\hline BI, 0-10 & Decomposed peat & $8350 \pm 60$ & $9369 \pm 72$ & -31.9 & UtC-7431 & Raab, 2003 \\
\hline $\mathrm{KI}$, margin of ice cap & Plant remains? & $6990 \pm 170$ & $7831 \pm 148$ & & IGRAN-879 & Stiévenard et al., 1996 \\
\hline
\end{tabular}

* plant remains are unidentified in these samples.

All radiocarbon ages are normalized to a $\delta^{13} \mathrm{C}$ of $-25 \%$ vs PDB. 
Arctic pollen records (Andreev et al. 2003, 2004a,b, 2005, in press). In the present study, we used the reference data set of 1173 modern pollen spectra from Northern Eurasia (for details see Tarasov et al. 2005). The BMA method uses a chord distance to determine the dissimilarity between fossil pollen spectra and spectra in the modern data set. In the present study, eight spectra with the smallest chord distance were considered as the closest modern analogues to the fossil spectrum. An empirical check used the surface data set shown that eight spectra are giving the best result in reconstructing modern climate at the surface pollen sampling sites (Tarasov et al., 2005). Then the reconstructed value (treated as the most probable) was calculated as the weighted average of the climatic variables of the selected best analogues, with the inverse of the chord distance as weights (Tarasov et al., 2005).

The samples prepared for rhizopod analyses were wet-sieved through a $500 \mu \mathrm{m}$ screen to remove organic and mineral particles that prevented identification of rhizopods. Rhizopod taxa were identified in a water suspension with a drop of glycerol on a slide, within $24 \mathrm{~h}$ of preparation. The samples were investigated under a light microscope at 200-400× magnifications. On average, five slides were examined for each sample. Study of a sample was terminated if no rhizopod shells were identified in the first two slides.

\section{Results and discussion}

\subsection{SZ-2 section (late Pleistocene and ca. 11,200 cal. yr BP)}

The oldest pollen spectrum occurs in the lowermost part of the SZ2 profile (Fig. 2). It is dominated by Poaceae, Artemisia, and Cyperaceae with a few other pollen and palynomorphs. The pollen concentration is very low. These sediments are older than $11,200 \mathrm{cal}$. yr, based on the age of macrofossils from the overlying peat horizon (Table 2). Similar Poaceae-Artemisia dominated spectra are found in the undated loesslike sediments of the Changeable Lake basin (Makeyev et al., 1992; Bolshiyanov and Makeyev, 1995). The pollen taxa indicate rather warm but relatively dry conditions, characteristic of a late Pleistocene open steppe-like vegetation on northern Taymyr (Andreev et al., 2002b, 2003). The lack of erosional indicators above our Severnaya
Zemlya sample combined with similarity in pollen spectra to northern Taymyr suggests a late Pleistocene age, possibly from the Allerød period (ca. 14,000-13,000 cal yr BP).

An Allerød age is consistent with several additional lines of indirect evidence. The SZ-2 samples include spores of dung-inhabiting fungi, Sordaria (van Geel and Aptroot, 2006), indicating the presence of grass-eating animals on the island during the time of sediment accumulation. This result fits previous radiocarbon dates of several mammoth bones found on Severnaya Zemlya (Arslanov et al., 1980). The youngest of these bones, a tusk, yielded an Allerød age of 13,403 \pm 121 cal. yr BP. A similar tusk age, $12,254 \pm 214$ cal. yr BP, is also reported by Möller et al. (2007). The remaining mammoth ages of ca. 30,000 and 24,000 cal. yr BP are consistent with the Lake Changeable core data and relative sea-level observations showing the absence of substantial ice over Severnaya Zemlya during the Last Glacial Maximum from ca. 22,000 to 18,000 cal. yr (Raab et al., 2003; Möller et al., 2007). There is also an interesting single radiocarbon age of $13,440 \pm 455$ cal. yr BP from the "lake-bog" sediments of Bolshiyanov and Makeyev (1995) that suggests possible accumulation of terrestrial organics in Allerød time.

The pollen concentration is much higher in the peaty layers dated to $11,229 \pm 20$ cal. yr BP. The spectrum is dominated mostly by Poaceae and Cyperaceae, although with a large number of Betula sect. Nanae and Salix pollen indicating significant climate amelioration after the late Glacial/Holocene transition. Single pollen grains of exotic tree and shrub pollen probably originated from long-distance sources. Bolshiyanov and Makeyev (1995) also mentioned similar pollen spectra from their "lake-bog" sediments, radiocarbon dated to $11,477 \pm 177$ and $10,983 \pm 170$ cal. yr BP. Typical wetland taxa dominate the rhizopod communities at SZ-2 (Table 3).

Thus, the ca. 11,200 cal. yr period (early Preboreal) at the SZ-2 site was characterized by open tundra and dwarf-shrub tundra associations. The local environment was rather humid. Results of the climate reconstruction by the BMA method suggest warmer-than-present conditions with the mean temperature of the warmest month at least $4{ }^{\circ} \mathrm{C}$ higher than modern and accumulated mean daily temperatures above $5{ }^{\circ} \mathrm{C}$ (so-called growing-degree-days, GDD5 (Prentice et al., 1992) between 200 and $300{ }^{\circ} \mathrm{C}$. The reconstructed values of annual

\section{SZ-2 $\left(7^{\circ}{ }^{10} 0^{\prime} 57^{\prime} \mathrm{N}, 9^{\circ} 30^{\prime} \mathrm{E}\right)$}

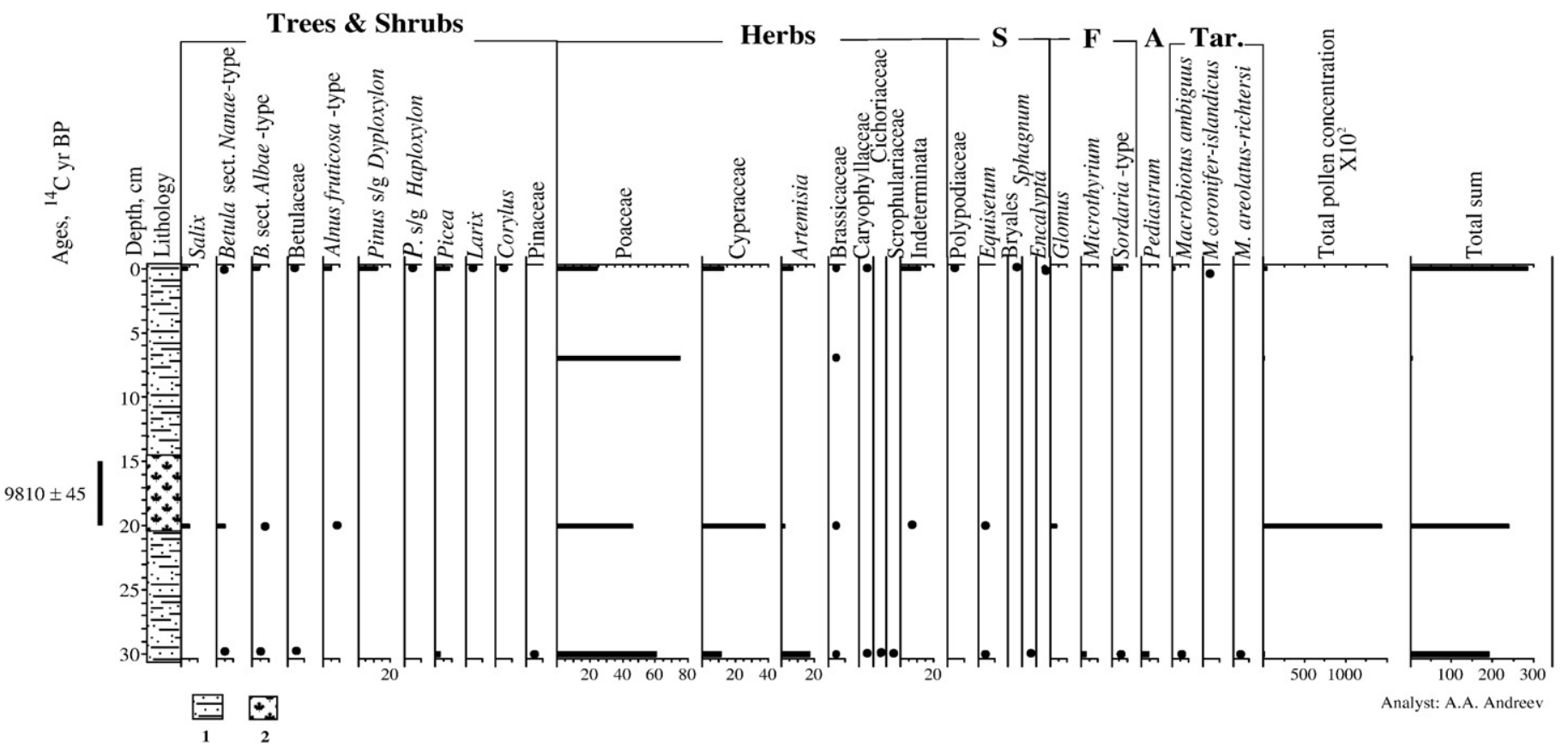

Fig. 2. Pollen and non-pollen palynomorphs percentage diagram of section SZ-2. 1 -clayey silt, 2 -silty peat, ${ }^{\bullet}$-presence less than $1 \%$. 
Table 3

List of rhizopod species found in the studied deposits from the October Revolution and Bolshevik Islands. Ecological preferences are according Chardez (1965): sh-Sphagnum, m-green moss, s-soils, w-water

\begin{tabular}{|c|c|c|c|c|c|c|c|c|c|c|c|c|c|c|c|c|c|c|c|c|c|}
\hline Taxa & 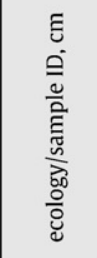 & $\begin{array}{l}\circ \\
\text { N் } \\
\text { N }\end{array}$ & 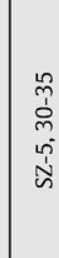 & $\begin{array}{l}\text { 우 } \\
\text { m } \\
\text { ஸ́ } \\
\text { N }\end{array}$ & 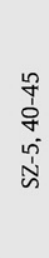 & 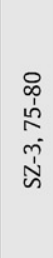 & $\begin{array}{l}\text { ㅇ } \\
\text { ¿্ } \\
\text { స่ }\end{array}$ & $\begin{array}{l}\text { ㅇ } \\
\text { ص் } \\
\text { N่ }\end{array}$ & 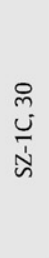 & $\begin{array}{l}8 \\
\text { テे } \\
\text { N }\end{array}$ & $\begin{array}{l}\text { กn } \\
\text { ஸ́ } \\
\text { ฟ் } \\
\text { N }\end{array}$ & $\begin{array}{l}\text { ஸे } \\
\text { ஒ் } \\
\text { ஸे }\end{array}$ & 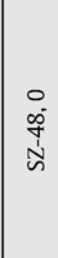 & $\begin{array}{l}8 \\
\infty \\
\text { ஸे } \\
\text { N } \\
\text { in }\end{array}$ & 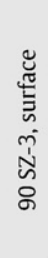 & $\begin{array}{l}\infty \\
\dot{\sigma} \\
\sigma\end{array}$ & $\stackrel{n}{\bar{m}}$ & $\stackrel{n}{\vec{n}}$ & $\frac{\stackrel{N}{~}}{\stackrel{\sim}{\sim}}$ & $\begin{array}{l}\tilde{0} \\
0 \\
\overline{0} \\
\Xi\end{array}$ & 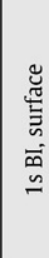 \\
\hline \multicolumn{22}{|l|}{ Eurybiotic and soil species } \\
\hline Centropyxis aerophila & $\mathrm{m}$ & 1 & 4 & 5 & & & 6 & 5 & 6 & 1 & & 5 & 3 & & 1 & 4 & 1 & 1 & 2 & 2 & 1 \\
\hline C. aerophila v. grandis & $\mathrm{w}$ & & & & & & 5 & & 3 & & & & & & 1 & 1 & & & & & \\
\hline C. aerophila v. minuta & wms & & 13 & 6 & & & & & & & & & & & & & & & & & \\
\hline C. cassis & shsbm & & & & & & 1 & & & & & & & & 0 & 3 & & & & & \\
\hline C. constricta & ws & & 1 & 2 & & & 5 & 10 & 3 & & & 1 & 2 & & 1 & & & & & & \\
\hline C. constricta $v$. minima & w & 1 & 26 & 13 & & & 9 & 2 & 8 & 1 & & 33 & 21 & & 9 & 4 & 8 & 2 & & & 7 \\
\hline C. kahli & wm & & & 3 & & & & & & & & & & & & & & & & & \\
\hline C. sylvatica & wshm & & 1 & 1 & & & 1 & 2 & 1 & & 1 & 1 & 6 & & 2 & 1 & 2 & & & 8 & 2 \\
\hline C. sylvatica v. minor & shs & & 5 & 2 & & & & & & 1 & 1 & 3 & 4 & & & & 10 & 10 & & 1 & \\
\hline \begin{tabular}{|l} 
Cyclopyxis sp. \\
\end{tabular} & & & & & & & & 2 & & & & & & & & & & & & & \\
\hline C. eurystoma v. parvula & $s$ & & 23 & 15 & & & & & & & & & 4 & & & 4 & 6 & 13 & & & 1 \\
\hline Euglypha cuspidata & swbm & & & & & & & & & & & & & & & 2 & & 1 & & & \\
\hline E. laevis & swbm & & & & & & & & & & & & 27 & & & 11 & & 2 & 2 & & \\
\hline E. laevis $v$. lanceolata & swbm & & & & & & & & & & & & 1 & & & & & & & & \\
\hline \begin{tabular}{|l|} 
Plagiopyxis declivis \\
\end{tabular} & shs & & & & & & & & & & & & & & & & & 1 & 1 & & \\
\hline P. cf. labiata (forma longa) & shm & & & & & & & & & & & & & & & & & & & 1 & 13 \\
\hline Schoenbornia humicola & $s$ & & & & & & & & & & & & 31 & & & & & & 1 & 2 & 8 \\
\hline Sch. cf. viscicula & $\mathrm{s}$ & & & & & & & & & & & & 8 & & & & & & & & \\
\hline Trinema enchelys & wshm & & & & & & & & & & & & & & & 1 & & & & & \\
\hline \begin{tabular}{|l} 
T. lineare \\
\end{tabular} & wshms & & & & & & & & & & & & 26 & & & 10 & 3 & 5 & & & \\
\hline \multicolumn{22}{|l|}{\begin{tabular}{|l} 
Calceophilic \\
\end{tabular}} \\
\hline C. plagiostoma & $\mathrm{s}$ & & 4 & 5 & & & & & & & & 2 & 13 & & & & & & & 1 & \\
\hline C. plagiostoma (forma major) & $\mathrm{s}$ & & 3 & & & & & & & & & 1 & 3 & & & & & & & & \\
\hline C. plagiostoma (forma minor) & $\mathrm{s}$ & & 6 & & & & & & & & & & & 1 & 1 & & & 1 & 1 & 1 & \\
\hline \multicolumn{22}{|l|}{ Sphagnophilic } \\
\hline Arcella arenaria $v$. compressa & $\mathrm{m}$ & 6 & & & 3 & 1 & & & 2 & & & & & & & & & & & & \\
\hline Assulina muscorum & $\mathrm{m}$ & & & & & & & & & & & & & & & & & & & 2 & 16 \\
\hline Centropyxis aculeata & w & 1 & 7 & 3 & 1 & 2 & & & & & 1 & & & & & 5 & & & & & \\
\hline C. aculeata v. minor & $\mathrm{w}$ & & & & 1 & & & & & & & & & & & & & & & & \\
\hline C. cf capucina & shms & & & & & & & & & & & & & & & & & & & & 3 \\
\hline C. discoides & w & & 1 & & & & & & & & & & & & & & & & & & \\
\hline C. ecornis & w & & & & & & & 2 & & & & & & & & & & & & & \\
\hline C. ecornis v. megastoma & $\mathrm{w}$ & & & & & & & 4 & & & & & & & & & & & & & \\
\hline C. orbicularis & wshm & & & + & & & 1 & & & & & & & & & & & & & & \\
\hline C. platystoma & swm & & & & & & & & & & & 3 & & & & & & & & & \\
\hline C. sp. & & & & & & & & & & & & & & & & 3 & & & & & \\
\hline Corythion dubium $v$. orbicularis & $\mathrm{m}$ & & & & & & & & & & & & & & & & & & & & 6 \\
\hline Euglypha strigosa (forma glabra) & swbm & & & & & & & & & & & & & & & & & & & & 1 \\
\hline Hyalosphenia minuta & sh & & & & & & & & & & & & & & & & & & & & \\
\hline H. sp. & & & & & & & 1 & & & & & & & & & & & & & & \\
\hline Heleopera petricola & wsh & 2 & 1 & & 3 & 2 & & & 1 & 2 & 2 & & & & & 1 & & & & & \\
\hline H. petricola $v$. amethystea & wsh & & & & & & & & & & & & & & & 3 & & & & & \\
\hline H. $s p 1$ & & & 1 & & & & & & & & & & & & & & & & & & \\
\hline H. $s p 2$ & & & & 1 & & & & & & & & & & & & & & & & & \\
\hline Nebela tincta & shms & & & & & & & & & & & & & & & 6 & & & & & \\
\hline N. cf. tincta. & shms & 2 & & & 2 & & 2 & 2 & & & & & & & & & & & & & \\
\hline N. minor & & & & & & & & & & & & & & & & 1 & & & & & \\
\hline \begin{tabular}{|l|} 
Plagiopyxis callida \\
\end{tabular} & wshms & & & & & & & & 1 & & & & & & & & & & & & \\
\hline P. minuta & $\mathrm{ms}$ & & & & & & & & & & & & & & & & & & & 1 & \\
\hline \begin{tabular}{|l|} 
Trigonopyxis arcula \\
\end{tabular} & shm & & & & & & & 2 & & & & & & & & & & & & & \\
\hline \multicolumn{22}{|l|}{\begin{tabular}{|l|} 
Hydrophilic \\
\end{tabular}} \\
\hline \begin{tabular}{|l|} 
Difflugia globularis \\
\end{tabular} & $w$ & & & & & & & & 4 & & & & & & & & & & & & \\
\hline D. globulosa & $w$ & & & & & & & 3 & & & & & & & & 1 & & & & & \\
\hline D. penardi & $w$ & & & & 1 & & & & & & & & & & & & 1 & & & & \\
\hline D. lucida & wshm & & & & & & & & & & & & 5 & & & & & & & & \\
\hline D. sD. & & & & 1 & & & & & & & & & & & & & & & & & \\
\hline
\end{tabular}


precipitation suggest that precipitation was similar or slightly higher than present during the early Holocene. Similar palaeoenvironmental changes with warmer conditions have been recorded in nearby sites in the Eurasian Arctic (e.g. Andreev et al., 1997b; Serebryanny et al., 1998; Andreev et al., 2001, 2002a,b, 2003, 2004a, 2005, in press and references therein).

\subsection{SZ-5 section (ca. 10,500 cal. yr)}

The vegetation composition reconstructed from the SZ-5 profile (Fig. 3) was similar to the ca. 11,200 cal. yr samples from SZ-2. Its age, however, is probably a few hundred years younger as shown by radiocarbon results of $10,670 \pm 57$ and $10,415 \pm 91$ cal. yr BP. High amounts of Cyperaceae in these spectra reflect a local wetland environment. The environmental conditions during this interval were probably the most favourable of the Holocene for vegetation.

The peat also contains rhizopod tests (Table 3). Two sphagnophilic taxa (Centropyxis aculeata and Heleopera petricola) in the bottom of section SZ-2 suggest oligotrophic peatland conditions. Eurybiotic (Centropyxis aerophila, C. aerophila v. minuta, C. sylvatica, C. sylvatica v. minor, Cyclopyxis eurystoma v. parvula), sphagnophilic (C. aculeata), and hydrophilic (Difflugia oblonga, D. pristis) species found in the upper peat layer point to a significantly wetter habitat. Generally, the high species diversity (13 species and infraspecific forms) reflects a more favourable soil environment than at the beginning of the peat accumulation. Moreover, testate amoebae palaeocommunities reflect richer and less acid environments (presence of calceophilic Centropyxis plagiostoma). Later, around ca. 10,400 cal. yr, the hydrophilic Difflugia disappeared from the communities, suggesting drier conditions, while calceophilic $C$. plagiostoma increased. The uppermost peat layer contains no rhizopod shells reflecting environmental conditions unfavourable for rhizopods.

\subsection{OR section (undated, ca. 11,000-10,500 cal. yr?)}

The undated peaty sediment from an old delta sediments of the Ozernaya River (Fig. 4) may have accumulated contemporaneously with the SZ-2 and SZ-5 sections because its spectra show similar low concentrations of long-distance transported Alnus fruticosa (alder) pollen. Later, after 10,200 cal yr, alder pollen was more common, as shown in sections SZ-3 and SZ-1a-c (Figs. 5-6). Thus, sedge-grass communities dominated the vegetation around the OR section shortly before 10,200 cal. yr (probably between 11,000 and 10,500 cal. yr). The relatively high content of dwarf birch and willow pollen in the spectra indicates that these taxa grew in the area.

The Ozernaya River delta samples also contain tests of rhizopods (Table 3). Testate amoebae (mostly eurybiotic species) from the bottom of the profile reflect rather dry soil conditions. Rhizopods from the upper samples indicate a gradual increase of soil moisture as the number of typical bog and hydrophilic taxa (Difflugia globulus, D. penardi, Centropyxis platystoma) increased and reached their maxima at $50 \mathrm{~cm}$ depth. The rhizopod community from the uppermost sample records rather high species diversity (14 taxa from all ecological groups). It also reflects a rich mineral nutrition (presence of calceophilic C. plagiostoma). The tests of hydrophilic Difflugia lucida, inhabitant of peaty soils, point to a high moisture content.

\subsection{SZ-3 section (ca. 10.200 cal. yr)}

The SZ-3 profile (Fig. 5) is radiocarbon dated to $10,199 \pm 31$ cal. yr BP. Its pollen spectrum is dominated by Cyperaceae pollen with some Salix, Betula sect. Nanae, Alnus fruticosa, and Brassicaceae pollen. The pollen concentration is high. The presence of shrub alder pollen probably does not point to a local source, but rather that pollen was sourced from expanded alder populations on mainland Eurasia (e.g. Andreev et al., 1997b; Macdonald et al., 2000; Andreev et al., 2001, 2002a,b, 2003, 2004a,b, 2005 and references therein). Open tundra and dwarf-shrub tundra associations dominated the vegetation at ca. 10,200 cal. yr. Low species diversity characterizes the rhizopod community from the peat with the dominance of sphagnophilic taxa (Table 3).

\subsection{SZ-1 sections (ca. 9700 cal. yr)}

The three closely situated peat-silt profiles (SZ-1a-c, Fig. 6) yield similar pollen spectra. In particular, the abundance of long-distance transported pollen (mostly Alnus fruticosa) is much higher than in the

\section{SZ-5 (79¹0'16' N, $\left.95^{\circ} 16^{\prime} 29^{\prime \prime} \mathrm{E}\right)$}

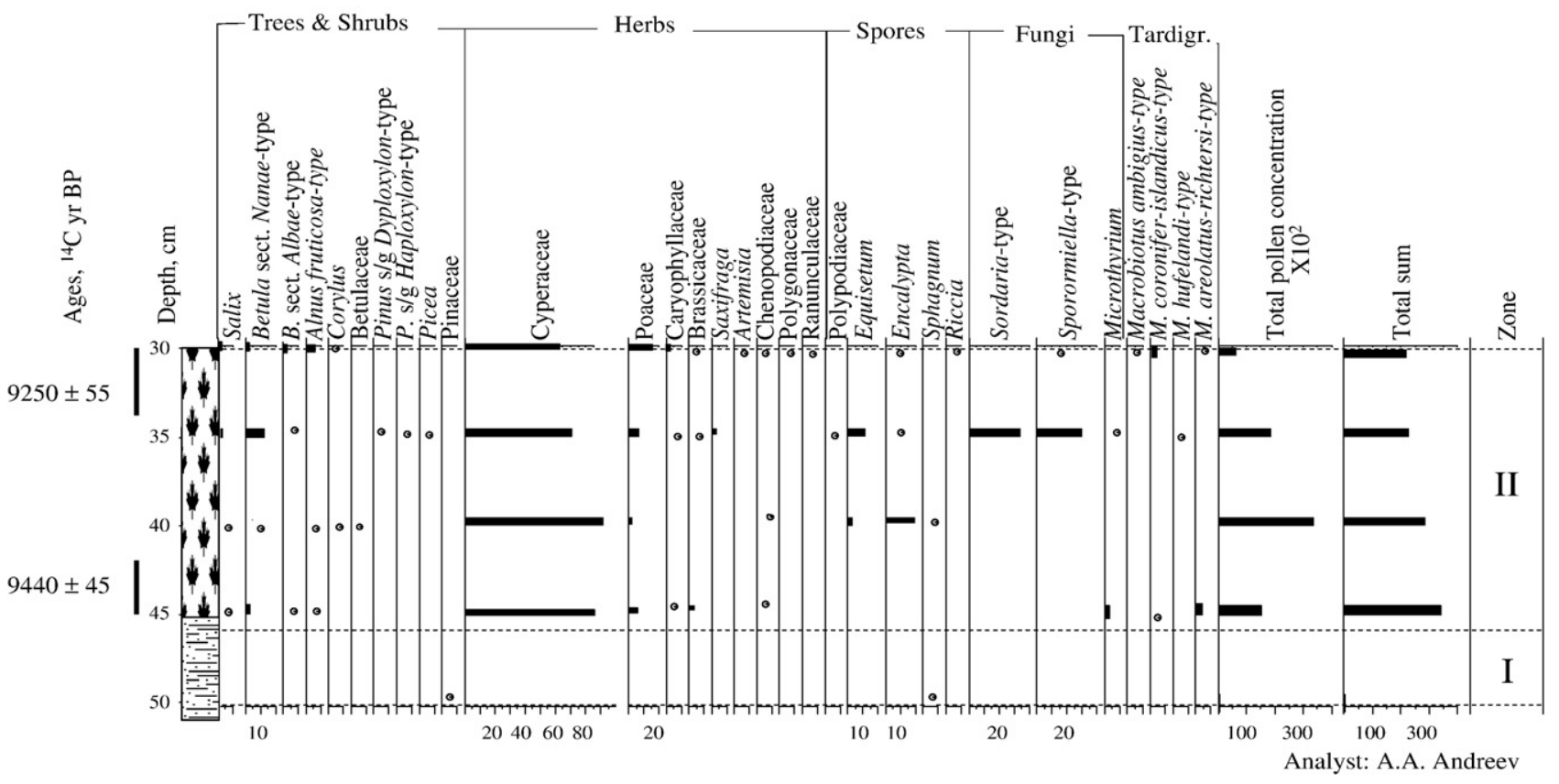

Fig. 3. Pollen and non-pollen palynomorphs percentage diagram of section SZ-5. For legend see Fig. 2. 
older pollen spectra for ca. 10,400 cal. yr. The age of the SZ-1 peat is constrained by two radiocarbon dates on plant macrofossils: $9811 \pm$ 145 and $9569 \pm 50$ cal. yr BP. Plant remains from a nearby location were dated by Bolshiyanov and Makeyev (1995) and yielded a similar age of $9884 \pm 250$ cal. yr BP, but there is no additional information about the dated sample.

Rhizopod communities from the SZ-1 profiles reflect a rather wet moss habitat. Generally, the number of bog inhabitants is relatively high, although, species diversity (eight species) is rather low in the older sample. The sphagnophilic and hydrophilic (Difflugia globulosa) taxa are more numerous (11 taxa) in the younger sample pointing to a wetter local environment compared to other SZ-1 samples (Table 3).

\subsection{BI section (ca. 9900-9400 cal. yr)-Bolshevik Island}

Peaty sediments from the bottom of a hummock near Solnechnaya Bay on Bolshevik Island (Raab, 2003; BI profile) yielded three ages between 9900 and 9400 cal. yr (Table 2). Two samples from this $13 \mathrm{~cm}$-thick peat monolith have been also studied for pollen (Raab, 2003). The spectra are dominated mostly by Cyperaceae and Poaceae with few other herb pollen taxa like Brassicaceae and Saxifraga reflecting environmental conditions similar to those on October Revolution Island at ca. 9500 cal. yr BP. Long-distance transported Alnus and Betula are also common in the studied samples.

A total of 17 species, varieties, and forms of rhizopod were found in the bottom of the studied BI monolith (Table 3). The inferred fossil community consists of wetland and eurybiotic taxa. The high species diversity indicates a favourable, wet soil environment. The rhizopods from the upper part of the BI monolith demonstrate the gradual disappearance of typical bog taxa and dominance of eurybiotic and drier soil taxa (Table 3). The presence of calceophilic C. plagiostoma (xerophytic forma minor) and the soil taxon, Plagiopyxis declivis at a depth of $5 \mathrm{~cm}$ in the monolith points to an enhanced mineral supply and rather xerophytic conditions. The litter inhabitant Schoenbornia humicola, found at a depth of $2 \mathrm{~cm}$ in the monolith indicates dry soil conditions.

The remains of soil ticks found in the BI peaty monolith belong to taxa currently restricted to Arctic tundra on mainland Arctic Eurasia (O. Makarova, Severtsev Institute of Ecology and Evolution Moscow, personal communication). Their presence indicates mean summer temperatures were ca. $4{ }^{\circ} \mathrm{C}$ higher than current conditions.

\subsection{Peat accumulation}

Our results combined with prior research suggest that peat accumulation on Severnaya Zemlya was limited mostly to the early Holocene from ca. 11,500 to 9500 cal. yr (Table 2). We did not find peaty sediment younger than $9569 \pm 50$ cal. yr BP on October Revolution Island, but prior studies have produced five younger ages: four from October Revolution Island (3664 $\pm 124,3534 \pm 145$, $3434 \pm 116$, and $1270 \pm 869$ cal. yr BP; Bolshiyanov and Makeyev, 1995) and one from the margin of the Academy of Science Ice Cap on Komsomolets Island (7831 \pm 148 cal. yr BP; Stiévenard et al., 1996). Unfortunately, there is no additional information concerning these younger samples, which could be used to reconstruct palaeoenvironmental conditions.

The overall distribution of published ages suggests a reduction in peat accumulation after ca. 9500 cal. yr. The cause of this apparent deterioration of local environmental conditions remains unknown. Potential factors include decreasing summer insolation and rising sea level, the latter causing cold sea-ice laden water to move across the shallow Kara Sea shelf and closer to the sample sites, especially those on October Revolution Island.

OR $\left(79^{\circ} 10^{\prime} \mathrm{N}, 96^{\circ} 40 ' \mathrm{E}\right)$

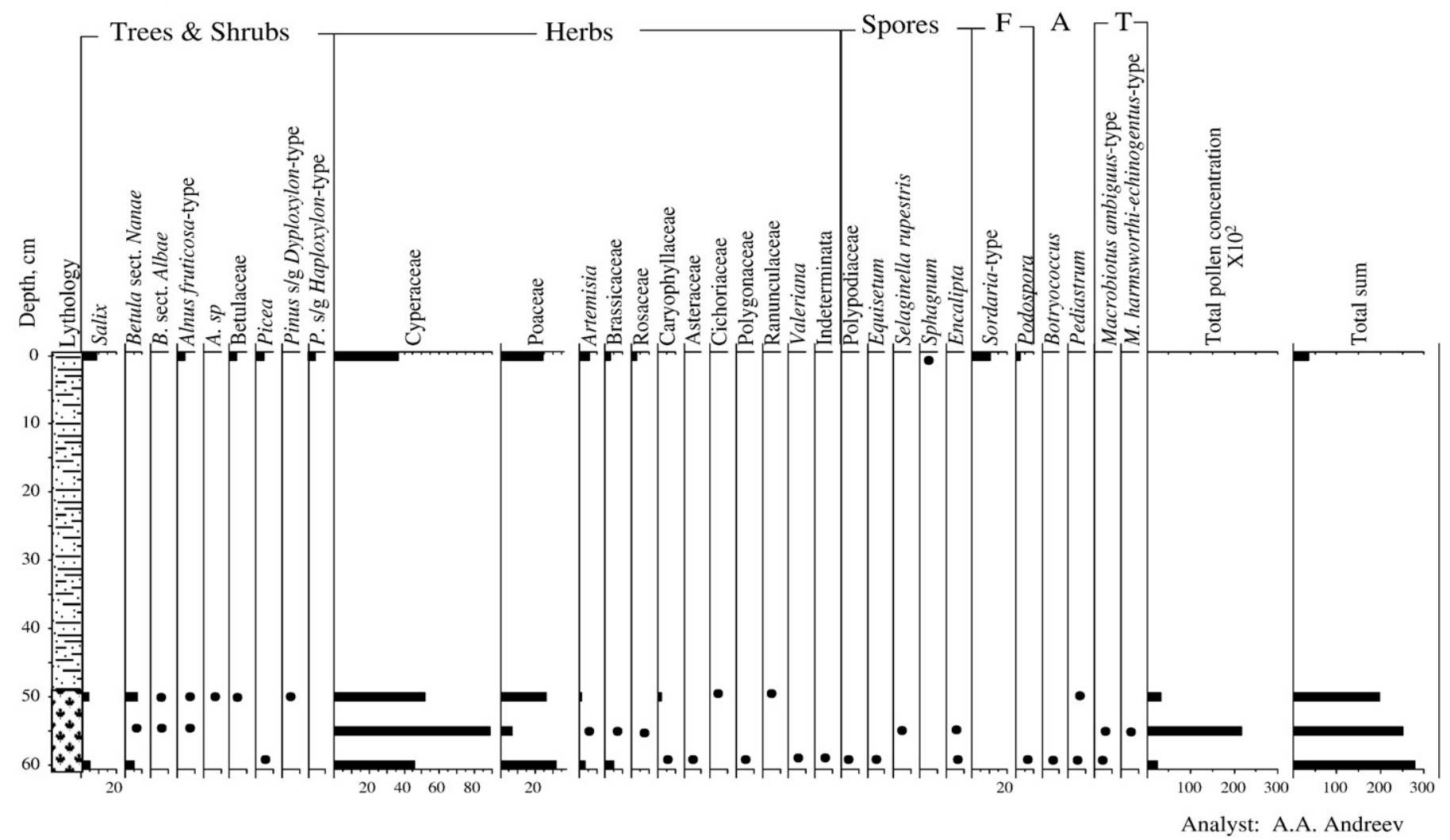

Fig. 4. Pollen and non-pollen palynomorphs percentage diagram of section OR. For legend see Fig. 2 . 
SZ-3 $\left(7^{\circ} 10^{\prime} 30^{\prime \prime} \mathrm{N}, 9^{\circ} 21 ' \mathrm{E}\right)$

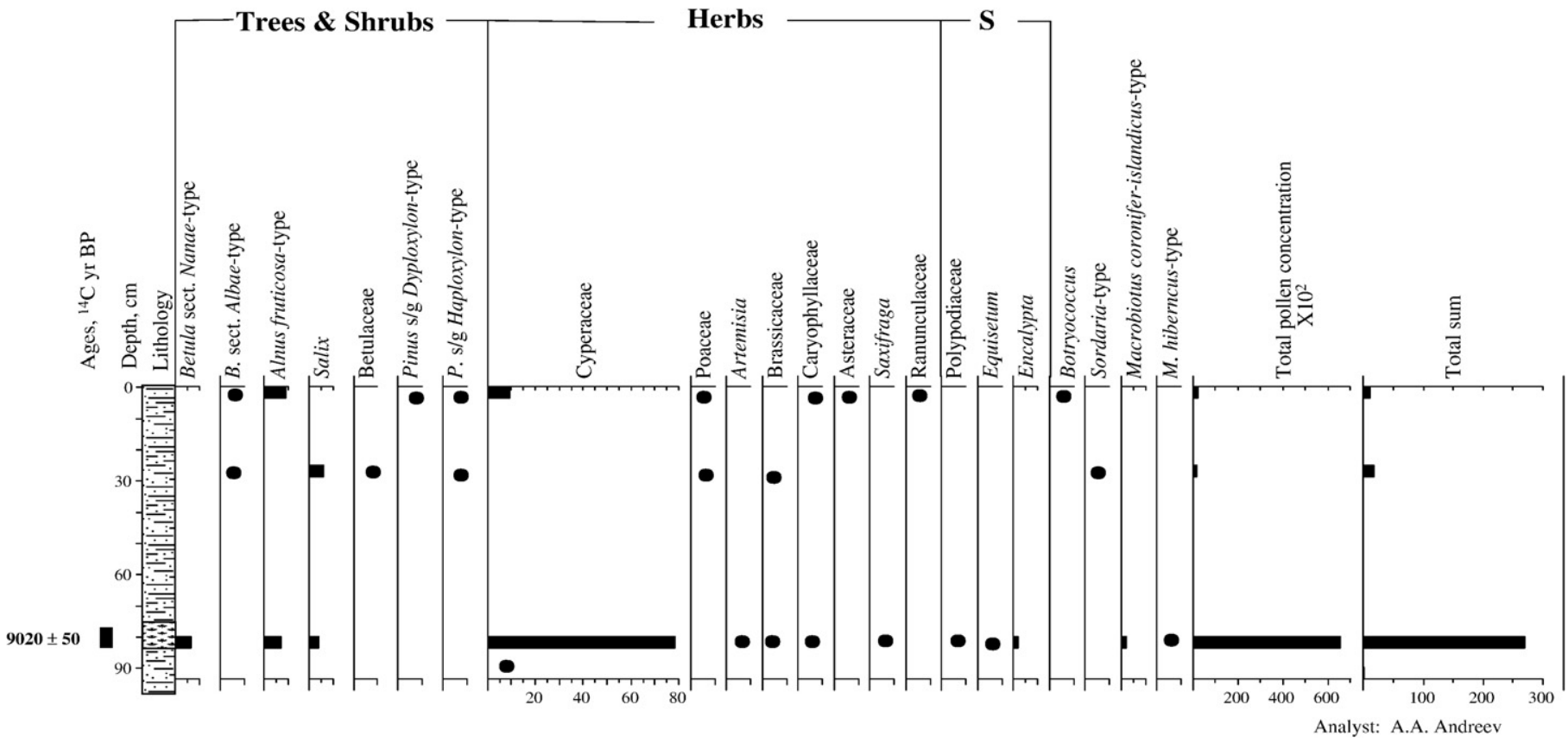

Fig. 5. Pollen and non-pollen palynomorphs percentage diagram of section SZ-3. For legend see Fig. 2.

4.8. Modern samples

Modern surface samples presented in Fig. 7 and subrecent spectra from SZ-2 (Fig. 2) and SZ-3 (Fig. 5) demonstrate high percentages of pollen transported long distances (mostly Pinus, Betula, and Alnus). Other common taxa, Poaceae and Cyperaceae, also may have been partially transported long distances. Previous studies of pollen from the October Revolution Island also indicate high amounts of long-

\section{SZ-1 (79 $\left.10^{\prime} 56^{\prime \prime} \mathrm{N}, 9^{\circ} 30^{\prime} 25^{\prime \prime} \mathrm{E}\right)$}

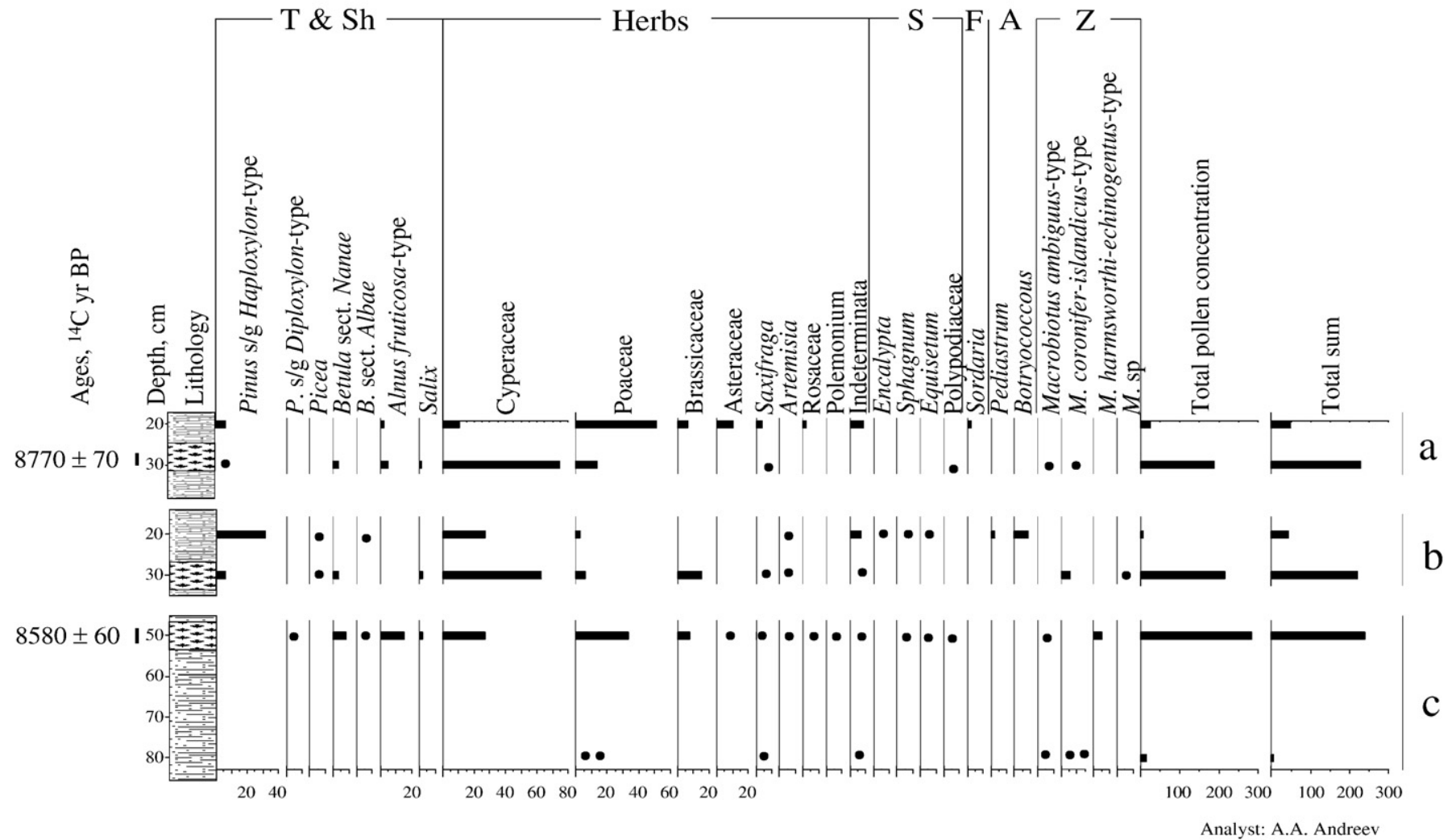

Fig. 6. Pollen and non-pollen palynomorphs percentage diagram of sections SZ-1. a-SZ-1A, b-SZ-1C, c-SZ-1B. For legend see Fig. 2. 


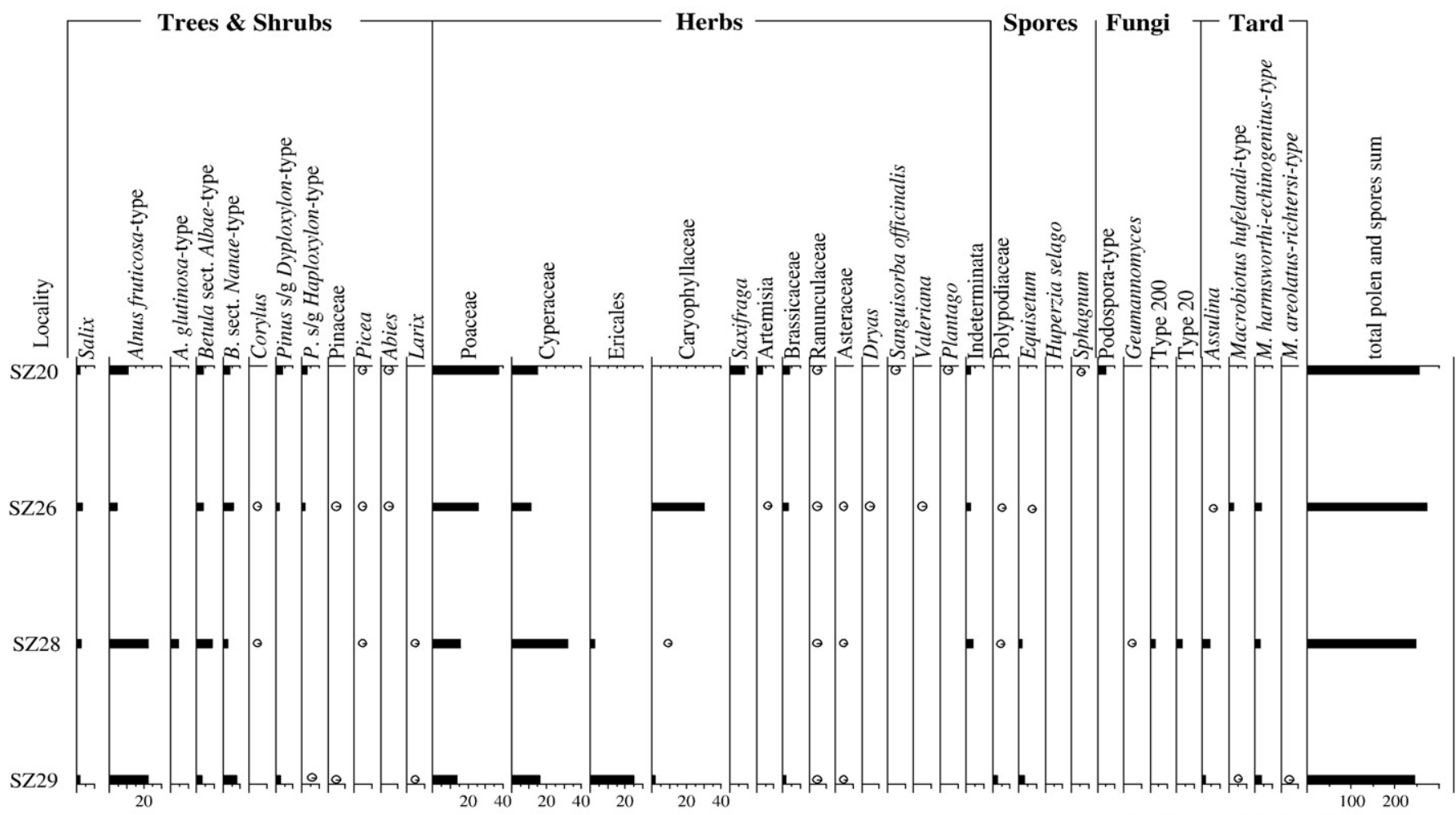

Analysts: S. Müller \& K. Werner

Fig. 7. Surface pollen spectra. For legend see Fig. 2.

distance transported pollen in late Holocene and recent spectra (Kalugina et al., 1981; Andreev et al., 1997b).

Rhizopods were found in only one surface sample from October Revolution Island (the top of the SZ-3 profile), where the community consists of few eurybiotic and soil taxa. The subrecent and recent samples from Bolshevik Island contain mostly soil and sphagnophilic taxa. Rare species, Centropyxis capucina and Plagiopyxis labiata (f. longa, not previously mentioned as an infraspecific form), were identified also in the recent sample (moss poster). Generally, species diversity is higher in the past and in modern communities from south Bolshevik Island.

\section{Conclusions}

Open Poaceae-Artemisia-Cyperaceae, steppe-like vegetation existed on October Revolution Island shortly before the late Glacial/ Holocene transition. Environmental conditions on the island were most favourable for local biota during the early Holocene ca. 11,5009500 cal. yr BP. Tundra-like sedge-grass communities dominated the vegetation. Low shrub tundra associations with dwarf birch and willow grew in more sheltered localities. The temperatures were at least $4{ }^{\circ} \mathrm{C}$ higher than today ca. $11,500-9500 \mathrm{cal}$. yr BP. Environmental conditions changed significantly around $9500 \mathrm{cal}$. yr, probably due to a combination of colder and drier conditions, with the vegetation similar to modern. Little is known about the vegetation and climate changes on October Revolution Island after ca. 9500 cal. yr.

\section{Acknowledgements}

Fieldwork was financially supported by a grant from the Swedish Research Council, given to Ó. Ingólfsson and P. Möller (contract no. G- 5103-20005347/2000) and by U.S. National Science Foundation collaborative grants NSF OPP 196182 and NSF OPP 0001885 to D. Lubinski and S. Forman, respectively. We thank Dr. O. Makarova from the Severtsev Institute of Ecology and Evolution Moscow for the samples from Bolshevik Island. Special thanks also goes to Prof. J.N. Haas and anonymous reviewers for the English improvement and valuable scientific comments on previous versions of the manuscript.

\section{References}

Andreev, A.A., Nikolaev, V.I., Bolshiyanov, D.Yu., Petrov, V.N., 1997a. Pollen and isotope investigations of an ice core from Vavilov Ice Cap, October Revolution Island, Severnaya Zemlya Archipelago, Russia. Geogr. Physique. et Quarter. 51, 379-389.

Andreev, A.A., Tarasov, P.E., Romanenko, F.A., Sulerzhitsky, L.D., 1997b. Younger dryas pollen records from Sverdrup Island (Kara Sea). Quat. Int. 41/42, 135-139.

Andreev, A.A., Manley, W.F., Ingólfsson, Ó., Forman, S.L., 2001. Environmental changes on Yugorsky Peninsula, Kara Sea, Russia, during the last 12,800 radiocarbon years. Glob. Planet. Change 31, 253-262.

Andreev, A.A., Schirrmeister, L., Siegert, Ch., Bobrov, A.A., Demske, D., Seiffert, M., Hubberten, H.-W., 2002a. Paleoenvironmental changes in north-eastern Siberia during the Upper Quaternary-evidence from pollen records of the Bykovsky Peninsula. Polarforschung 70, 13-25.

Andreev, A.A., Siegert, Ch., Klimanov, V.A., Dereviagin, A.Yu., Shilova, G.N., Melles, M., 2002b. Late Pleistocene and Holocene vegetation and climate changes in the Taymyr lowland, Northern Siberia reconstructed from pollen records. Quat. Res. 57, 138-150.

Andreev, A.A., Tarasov, P.E., Siegert, Ch., Ebel, T., Klimanov, V.A., Bobrov, A.A., Melles, M., Dereviagin, A.Yu., Lubinski, D.J., Hubberten, H.-W., 2003. Vegetation and climate changes on the northern Taymyr, Russia during the Upper Pleistocene and Holocene reconstructed from pollen records. Boreas 32, 484-505.

Andreev, A.A., Klimanov, V.A., Siegert, C., Melles, M., Lisitsina, O.M., Hubberten, H.-W., 2004a. Vegetation and climate changes around the Lama Lake, Taymyr Peninsula during the Late Pleistocene and Holocene reconstructed from pollen records. Quat. Int. 122, 69-84.

Andreev, A.A., Tarasov, P.E., Schwamborn, G., Ilyashuk, B.P., Ilyashuk, E.A., Bobrov, A.A., Klimanov, V.A., Rachold, V., Hubberten, H.-W., 2004b. Holocene paleoenvironmental records from Nikolay Lake, Lena River Delta, Arctic Russia. Palaeogeogr. Palaeoclimatol. Palaeoecol. 209, 197-217.

Andreev, A.A., Tarasov, P.E., Ilyashuk, B.P., Ilyashuk, E.A., Cremer, H., Hermichen, W.-D., Hubberten, H.-W., Wischer, F., 2005. Holocene environmental history recorded in the Lake Lyadhej-To sediments, Polar Urals, Russia. Palaeogeogr. Palaeoclimatol. Palaeoecol. 223, 181-203.

Andreev, A.A., Grosse, G., Schirrmeister, L., Kuzmina, S.A., Kuznetsova, T.V., Bobrov, A.A., Tarasov, P.E., Novenko, E.Yu., Meyer, H., Kienast, F., Kunitsky, V.V., in press. 
Weichselian and Holocene palaeoenvironmental history of the Bol'shoy Lyakhovsky Island, New Siberian Archipelago, Arctic Siberia. Boreas.

Arslanov, Kh.A., Makeyev, V.M., Baranovskaya, O.F., Malakhovskiy, D.B., Tertychnaya, T.V., 1980. Geochronology and some questions of palaeogeography of the second part of the late Pleistocene of Severnaya Zemlya. In: Ivanova, I.K., Kind, N.V. (Eds.) Geokhronologiya Chetvertichnogo Perioda. Nauka, Moscow, pp. 168-176 (in Russian).

Bassford, R.P., Siegert, M.J., Dowdeswell, J.A., Oerlemans, J., Glazovsky, A.F., Macheret, Y.Y., 2006. Quantifying the mass balance of ice caps on Severnaya Zemlya, Russian High Arctic. I: climate and mass balance of the Vavilov Ice Cap. Arct., Antarct., and Alp. Res. $38,1-12$.

Berglund, B.E., Ralska-Jasiewiczowa, M., 1986. Pollen analysis and pollen diagrams. In: Berglund, B.E. (Ed.), Handbook of Holocene Palaeoecology and Palaeohydrology. Interscience, New York, pp. 455-484.

Bolshiyanov, D.Yu., Makeyev, V.M., 1995. Arkhipelag Severnaya Zemlya: oledenenie, istoriya razvitiya prirodnoi sredy (Severnaya Zemlya Archipelago: Glaciation, Environmental History). Gidrometeoizdat, St. Petersburg (in Russian).

Chardez, D., 1965. Ecologie générale des Thécamoebiens (Rhizopoda, Testacea). Bull. Inst. agron. stn. rech. Gembloux 33 (3), 307-341.

Fritzsche, D., Schütt, R., Meyer, H., Miller, H., Wilhelms, F., Opel, T., Savatyugin, L.M. 2005. A 275 year ice-core record from Akademii Nauk ice cap, Severnaya Zemlya, Russian Arctic. J. Glaciol. 42, 361-366.

van Geel, B., Aptroot, A., 2006. Fossil ascomycetes in Quaternary deposits. Nova Hedvigia 82, 313-329.

Govorenkov, B.F., 1981. About soil formation in the conditions of polar desert on the October Revolution Island (Severnaya Zemlya). Trudy AANII 367, 132-141 (in Russian).

Grimm, E., 1991. TILIA and TILIAGRAPH. Illinois State Museum, Springfield, Illinois.

Guiot, J., 1990. Methodology of palaeoclimatic reconstruction from pollen in France. Palaeogeogr. Palaeoclimatol. Palaeoecol. 80, 49-69.

Kalugina, L.V., Malakhovskiy, D.B., Makeyev, V.M., Safronova, I.V., 1981. Some results of palynological investigation on Severnaya Zemlya archipelago in relation to the question of the transport of pollen and spores in the high Arctic. Polar Geogr. and Geol. 5, 27-34.

Khodachek, E.A., 1986. Main plant communities on the western part of the October Revolution Island (Severnaya Zemlya). Botan. Zhurnal. 71 (12), 1628-1638 (in Russian).

Korotkevich, E.S., 1958. Vegetation of Severnaya Zemlya. Botan. Zhurnal. 43 (5) 644-663 (in Russian).
MacDonald, G.M., Kremenetski, C.V., Velichko, A.A., Cwynar, L.C., Riding, R.T., Goleva, A.A., Andreev, A.A., Borisova, O.K., Edwards, T.W.D., Hammarlund, D., Szeicz, J.M., Forman, S., Gataullin, V.I., 2000. Eurasian treeline change linked to the North Atlantic. Quat. Res. 53, 302-311.

Makeyev, V.M., Arslanov, Kh.A., Garutt, V.E., 1979. Age of Severnaya Zemlya mammoths and some questions of palaeogeography of Late Pleistocene and Holocene. Doklady AN SSSR 245, 421-424 (in Russian).

Makeyev, V.M., Bolshiyanov, D.Yu., Malakhovskiy, D.B., Baranovskaya, O.F., Molod'kov, A.I., Ponomareva, D.P., 1992. Stratigraphy and geochronology of Severnaya Zemlya Pleistocene deposit. In: Punning, Ya.-M.K., Ivanova, I.K., Kind, N.V., Chihagova, O.A (Eds.), Geokhronologiya Chetvertichnogo Perioda. Nauka, Moscow, pp. 132-137 (in Russian).

Möller, P., Lubinski, D.J., Ingólfsson, Ó., Forman, S.L., Seidenkrantz, M.-S., Bolshiyanov, D. Yu., Lokrantz, H., Antonov, O., Pavlov, M., Ljung, K., Zeeberg, J.-J., Andreev, A., 2007. Severnaya Zemlya, Arctic Russia: a nucleation area for Kara Sea ice sheets during the Middle to Late Quaternary. Quat. Sci. Rev. 26, 1149-1191.

Prentice, I.C., Cramer, W., Harrison, S.P., Leemans, R., Monserud, R.A., Solomon, A.M. 1992. A global biome model based on plant physiology and dominance, soi properties and climate. J. Biogeogr. 19, 117-134.

Raab, A., 2003. Sedimente des Changeable-Sees, Oktoberrevolution-Inseln (Severnaja Zemlja) als Archive der Paläoumwelt Mittelsibiriens seit dem Frühweichsel. Ber Polar-Meeresforsch. 435.

Raab, A., Melles, M., Berger, G.W., Hagedorn, B., Hubberten, H.-W., 2003. Non-glacial paleoenvironments and the extent of Weichselian ice sheets on Severnaya Zemlya, Russian High Arctic. Quat. Sci. Rev. 22, 2267-2283.

Safronova, I.N., 1981. Flora of October Revolution Island. In: Korotkevich, E.S., Semenov, I.V., Govorukha, L.S. (Eds.), Severnaya Zemlya Ice Cover and Periglacial Studies. Gidrometeoizdat, Leningrad, pp. 142-150 (in Russian).

Serebryanny, L, Andreev, A. Malyasova, E. Tarasov, P. Romanenko, F, 1998. Late Glacial and early Holocene environments of Novaya Zemlya and the Kara Sea region of the Russian Arctic. Holocene 8 (3), 323-330.

Stiévenard, M., Nikolaev, V., Bolshiyanov, D.Yu., Fléhoc, C., Jouzel, J., Klementyev, O.L., Souchez, R., 1996. The bottom ice of Vavilov Ice Cap, Severnaya Zemlya archipelago. J. Glaciol. 42, 403-406.

Tarasov, P., Granoszewski, W., Bezrukova, E., Brewer, S., Nita, M., Abzaeva, M. Oberhänsli, H., 2005. Quantitative reconstruction of the last interglacial vegetation and climate based on the pollen record from Lake Baikal, Russia. Clim. Dyn. 25 , 625-637. 